\title{
Simple and Rapid Visual Detection Methods of Orf Virus by $B 2 L$ Gene based Loop-Mediated Isothermal Amplification Assay
}

\author{
Gnanavel Venkatesan ${ }^{1 *}$, Veerakyathappa Bhanuprakash ${ }^{1,2}$, Vinayagamurthy Balamurugan ${ }^{1,3}$, \\ Amit Kumar ${ }^{1}$, Durlav Prasad Bora ${ }^{1}$, Yogisharadhya Reveniah ${ }^{1}$, Sargam Arya ${ }^{1}$, Aparna \\ Madhavan $^{1}$, Dhanavelu Muthuchelvan ${ }^{1}$, Awadh Bihari Pandey ${ }^{1}$
}

\begin{abstract}
${ }^{1}$ Pox Virus Laboratory, Division of Virology, Indian Veterinary Research Institute, Nainital (Distt.), Mukteswar 263 138, Uttarakband, India; ' Indian Veterinary Research Institute, Hebbal, Bengaluru 560 024, Karnataka, India; ${ }^{3}$ Project Directorate on Animal Disease Monitoring and Surveillance, Hebbal, Bengaluru 560 024, Karnataka, India.
\end{abstract}

\begin{abstract}
Comparison of three different visual detection methods namely the presence of turbidity, color change due to addition of SYBR green I and hydroxynaphthol blue has been studied for a loop-mediated isothermal amplification assay (LAMP) in rapid diagnosis of orf virus as an alternate to gel based analysis. This orf virus specific LAMP assay targeted the amplification of $B 2 L$ gene sequence of the virus genome and shown specific amplification within $45 \mathrm{~min}$ at $60^{\circ} \mathrm{C}$ without any cross reactivity to other viruses of sheep and goats. Analytical specificity and sensitivity of the assay were evaluated by these visual detection methods and positive detection rates by LAMP and PCR assays over testing of clinical samples and cell culture adapted virus isolates were determined. B2L LAMP assay detected thirty-five (85.3\%) samples, whereas the conventional PCR shown only thirty-three (80.5\%) samples as positive from a total of forty one clinical samples tested. On analysis of these thirty five positive samples by three visual detection methods, it is found that HNB and SYBR green I dyes are equally sensitive (100\%) and higher compared to turbidity method (94\%) of monitoring the LAMP reaction. Use of HNB dye in B2L LAMP assay will be affordable in terms of cost involved and ease of visualization and can suit the less equipped field laboratories for rapid clinical diagnosis of orf virus in sheep and goats.
\end{abstract}

Keywords | Orf virus, Diagnosis, LAMP, HNB, SYBR green I

Editor | Kuldeep Dhama, Indian Veterinary Research Institute, Uttar Pradesh, India.

Received | January 20, 2016; Revised | February 22, 2016; Accepted | February 25, 2016; Published | March 12,2016

*Correspondence | Gnanavel Venkatesan, Indian Veterinary Research Institute, Nainital (Distt.), Mukteswar 263 138, Uttarakhand, India; Email: gnanamvirol@ gmail.com

Citation | Venkatesan G, Bhanuprakash V, Balamurugan V, Kumar A, Bora DP, Reveniah Y, Arya S, Madhavan A, Muthuchelvan D, Pandey AB (2016). Simple and rapid visual detection methods of orf virus by B2L gene based Loop-mediated Isothermal amplification assay. Adv. Anim. Vet. Sci. 4(3): 152-159.

DOI | http://dx.doi.org/10.14737/journal.aavs/2016/4.3.153.160

ISSN (Online) | 2307-8316; ISSN (Print) | 2309-3331

Copyright (C) 2016 Venkatesan et al. This is an open access article distributed under the Creative Commons Attribution License, which permits unrestricted use, distribution, and reproduction in any medium, provided the original work is properly cited.

\section{INTRODUCTION}

$\mathrm{O}$ rf virus (ORFV), a member of the parapoxviruses, is the cause of papular dermatitis or contagious ecthyma or contagious papular dermatitis in sheep and goats reported globally (Hosamani et al., 2009) and the disease is also zoonotic causing local macula-papular lesions in humans by direct contact with infected animals (Lederman et al., 2007). This endemic disease incurs economic losses by causing severe morbidity in adults and mortality in young ones affecting farming community in India. In- creasing number of reports of contagious ecthyma in sheep and goats has been noticed worldwide recently (Abrahao et al., 2009; Chan et al., 2007; Guo et al., 2004; Hosamani et al., 2006; Mondal et al., 2006; Venkatesan et al., 2011; Zhao et al., 2010) and first time, in north eastern region of the country (Bora et al., 2012), indicating circulation of the virus and also the heterogeneity was reported in the Indian strains (Yogisharadhya et al., 2012).

Orf can easily be diagnosed based on clinical signs. However, the confounding clinical lesions similar to other vi- 
ral diseases such as foot and mouth disease and capripox demand laboratory confirmation by electron microscopy (EM), histopathology, specific serological tests such as Serum neutralization test (SNT), Complement fixation test (CFT), Enzyme linked immunosorbent assay (ELISA) and recently nucleic acid based assays namely polymerase chain reaction (PCR) (Inoshima et al., 2000; Bora et al., 2011) and real-time PCR (Gallina et al., 2006; Nitsche et al., 2006; Bora et al., 2011; Venkatesan et al., 2012). The conventional diagnostic approaches are labour intensive, time consuming and subjective in nature whereas, the PCR and real-time PCR methods are used for rapid diagnosis of ORFV. However, they demand technical expertise and equipment in resource limited field/rural diagnostic centres in developing countries. In recent past, the invention of the Loop mediated isolthermal amplification (LAMP) technique that can rapidly amplify nucleic acids with high specificity and sensitivity under isothermal conditions has overcome the pitfalls associated with above mentioned molecular diagnostics (Notomi et al., 2000). LAMP assay has been widely used in the detection of array of pathogens including viruses, bacteria and parasites (Parida et al., 2008). In this study, the LAMP assay targeting the $B 2 L$ gene of ORFV genome has been optimized and evaluated for the detection of ORFV isolates and clinical samples using visual detection approaches namely presence of turbidity, addition of hydroxynaphthol blue (HNB) and SYBR green I. These methods have been compared in terms of safety, cost and ease of detection of LAMP reaction as an alternate to agarose gel analysis which may cause contamination of LAMP reaction setting by aerosolization of previous reaction products during post LAMP reaction analysis.

\section{MATERIALS AND METHODS}

\section{Viruses and Cells}

Orf virus Mukteswar 59/05 (Vaccine strain) is used for optimization of $B 2 L$ gene based ORFV LAMP. Other ORFV isolates $(\mathrm{n}=07)$ and non-ORFV isolates $(\mathrm{n}=08)$ such as sheeppox virus (SPPV) and goatpox virus (GTPV) were also tested to analyze the specificity of the assay. Other viruses of small ruminants such as Peste des petits ruminant's virus (PPRV) and bluetongue virus (BTV) were used in checking the specificity of the assay. ORFV was propagated in primary lamb testes (PLT) cells, while other viruses in Vero cells using Eagle's minimum essential medium (EMEM) with $2 \%$ bovine calf serum. The infected cells were harvested after $80 \%$ cytopathic effect (CPE) using phosphate buffered saline (PBS, $\mathrm{pH}$ 7.2) for extraction of total viral genomic DNA. A total of 41 samples consisting of infected scab materials and virus isolates of different geographical origin were analysed by LAMP assay detected based on agarose gel analysis, presence of turbidity, addition of SYBR green I and HNB dyes and also the rate of detection by LAMP and conventional PCR was compared. Clinical samples as 10\% tissue homogenates and the harvested cell culture isolates were used for extraction of viral genomic DNA using a commercial DNA extraction kit as per manufacturer's protocol (AuPrep, Life technologies Pvt. Ltd., New Delhi, India).

\section{Designing of LAMP Primers}

Sequences of $B 2 L$ gene of $25 \mathrm{ORFV}$ virus isolates retrieved from GenBank were analyzed for conserved region using MegAlign program of DNASTAR version 6.0 of Lasergene software. The LAMP primers were designed using Primer Explorer V4 software based on a conserved region of the $B 2 L$ gene identified by sequence alignment report. The inner, outer and loop primers were synthesized commercially (M/s Metabion GmBH, Germany). The location of all the primers targeting $B 2 L$ gene in the genome is shown in Figure 1. The amplified region lies between nucleotide positions of 431 and 622 with a predicted amplicon size of $192 \mathrm{bp}$. Out of 6 primers, the outer primers F3 and B3 were used in conventional PCR to compare LAMP assay. The details of designed primers are mentioned in Table 1.

Table 1: List of primers used for detection of ORFV in LAMP assay

\begin{tabular}{|c|c|c|c|}
\hline $\begin{array}{l}\text { Primer } \\
\text { name }\end{array}$ & Type & Length & Sequence (5'-3') \\
\hline $\begin{array}{l}\text { ORFV } \\
\text { B2L F3 }\end{array}$ & Forward outer & 20 & $\begin{array}{l}\text { GCGAGTCCGAGAA } \\
\text { GAATACG }\end{array}$ \\
\hline $\begin{array}{l}\text { ORFV } \\
\text { B2L B3 }\end{array}$ & Backward outer & 19 & $\begin{array}{l}\text { TCAAGAACCTCGG } \\
\text { GCTCTA }\end{array}$ \\
\hline $\begin{array}{l}\text { ORFV } \\
\text { B2L FIP }\end{array}$ & $\begin{array}{l}\text { Forward } \\
\text { inner primer } \\
(\mathrm{F} 1 \mathrm{c}-\mathrm{F} 2)\end{array}$ & $\begin{array}{l}19(\mathrm{~F} 1 \mathrm{c}) \\
16(\mathrm{~F} 2)\end{array}$ & $\begin{array}{l}\text { GCTCTGCTGTGCC } \\
\text { GTCGTC-TTTT- } \\
\text { CCCCCGGAGTG- } \\
\text { GTTGA }\end{array}$ \\
\hline $\begin{array}{l}\text { ORFV } \\
\text { B2L BIP }\end{array}$ & $\begin{array}{l}\text { Backward inner } \\
\text { primer (B1- } \\
\text { B2c) }\end{array}$ & $\begin{array}{l}19(\mathrm{~B} 1) \\
18(\mathrm{~B} 2 \mathrm{c})\end{array}$ & $\begin{array}{l}\text { CGCGTGAACGGC } \\
\text { ACCTTCG- } \\
\text { TTTT-CTGGCCTG- } \\
\text { GGACCTCATG }\end{array}$ \\
\hline $\begin{array}{l}\text { ORFV } \\
\text { B2L LF }\end{array}$ & $\begin{array}{l}\text { Loop forward } \\
\text { primer }\end{array}$ & 19 & $\begin{array}{l}\text { CACGGCCACGAA } \\
\text { CTTCCAC }\end{array}$ \\
\hline $\begin{array}{l}\text { ORFV } \\
\text { B2L LB }\end{array}$ & $\begin{array}{l}\text { Loop backward } \\
\text { primer }\end{array}$ & 22 & $\begin{array}{l}\text { GGAGTAGAAGGT } \\
\text { GTTGTAGCGG }\end{array}$ \\
\hline
\end{tabular}

Optimization of LAMP and Conventional PCR Assays To optimize the standard conditions for LAMP, initially reaction was performed in different temperatures (60$\left.65^{\circ} \mathrm{C}\right)$ for varying time periods $(15-60 \mathrm{~min}$ at $15 \mathrm{~min}$ intervals) in a $25 \mu \mathrm{L}$ volume using purified ORFV genomic DNA (100ng), $1 \mathrm{X}$ ThermoPol buffer (New England Biolabs, Sumido, Tokyo, Japan), 8.0 mM MgSO4 (New England Biolabs, Japan), 0.8M Betaine (Sigma, USA), $0.8 \mathrm{mM}$ dNTPs, 8U Bst polymerase large fragment (New England Biolabs, Sumido, Tokyo, Japan), $0.2 \mu \mathrm{M}$ of each of the F3 
and B3 primers, $1.6 \mu \mathrm{M}$ of each of the FIP, BIP, LF and LB primers. After the end of LAMP, the reaction was terminated at $80^{\circ} \mathrm{C}$ for 2 min as per standardardized protocol mentioned earlier (Venkatesan et al., 2012) and checked in $2.5 \%$ agarose gel.

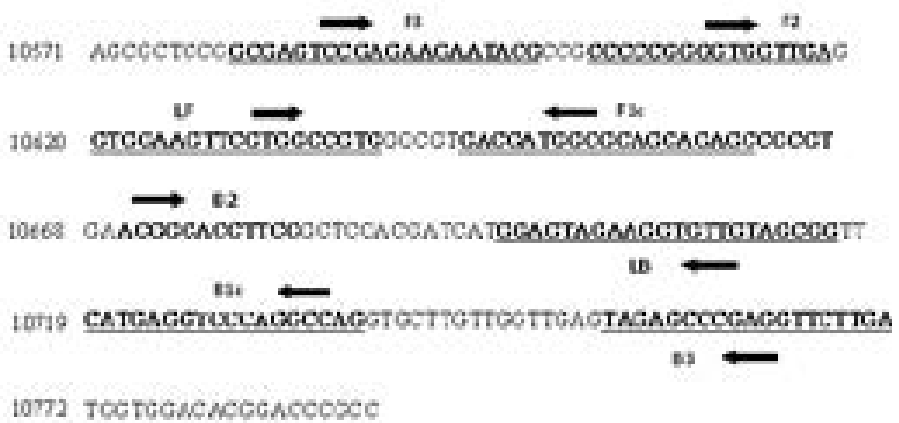

Figure 1: The location of LAMP primers in ORFV genome targeting $B 2 L$ gene

Gel based conventional PCR was optimized at different annealing temperature $\left(50-60^{\circ} \mathrm{C}\right)$ and the reaction was performed in a $25 \mu \mathrm{L}$ reaction containing 0.4 picomole as final concentration of each primer ( $\mathrm{F} 3$ and $\mathrm{B} 3$ primers of $B 2 L$ LAMP), $2.5 \mu \mathrm{L}$ of the 10x buffer (Fermentas, USA), $10 \mathrm{mM} / \mu \mathrm{L}$ each dNTPs, and 1IU of Taq DNA polymerase (M/s Fermentas, USA) using purified viral gDNA. Optimum PCR amplification was achieved by initial denaturation at $95^{\circ} \mathrm{C}$ for $5 \mathrm{~min}$ followed by 35 cycles each included denaturation step at $94^{\circ} \mathrm{C}$ for $30 \mathrm{~s}$, annealing step at $55^{\circ} \mathrm{C}$ for $30 \mathrm{~s}$ and extension step at $72^{\circ} \mathrm{C}$ for $30 \mathrm{~s}$ with a final extension step at $72^{\circ} \mathrm{C}$ for 7 min was included. Amplified product was cloned into pGEMT easy vector (Promega, Madison, USA) and standard plasmid construct made to analyse the detection limit of LAMP and conventional PCR assays.

\section{Sensitivity And Specificity of LAMP}

Total genomic DNA extracted from SPPV ( $n=5)$, GTPV $(\mathrm{n}=3)$, camelpox virus (CMLV, $\mathrm{n}=03$ ), buffalopox virus (BPXV, $\mathrm{n}=5)$ isolates available at the laboratory, mock infected PLT and Vero cells were included to determine the analytical specificity of the LAMP assay for ORFV. No template control (NTC) was also included as negative control in each test. To analyse the detection limit of LAMP and conventional PCR assays, the standard plasmid was diluted serially by 10 fold in Tris EDTA buffer (9x10 to $9 \times 10^{\circ}$ copies $\left./ \mu \mathrm{L}\right)$ and checked in both assays using optimized conditions. The resultant products were checked in $2.5 \%$ agarose gel stained by ethidium bromide $(\mathrm{EtBr})$. Additionally, the LAMP reaction was monitored by SYBR green I to know the sensitivity of the assay.

\section{VisUAL DETECTION OF LAMP}

In addition to $\mathrm{EtBr}$ stained agarose gel analysis of LAMP reaction, the alternate detection methods as a safe, simple and sensitive, point of care strategy were also optimized. The simple visual detection methods of LAMP based on presence of turbidity due to accumulation of magnesium pyrophosphate after reaction completed, colour change due to addition of SYBR green (original orange colour changes to apple green in positive reaction) and HNB (violet to sky blue in positive reactivity) dyes at the end of reaction were employed. All the three methods were optimized using different concentration of $\mathrm{MgSO} 4$ (New England Biolabs, Japan) responsible for turbidity formation, SYBR green I and HNB dyes to arrive at clear cut differentiation of positive and negative LAMP reaction.

\section{Evaluation of LAMP Assay}

A total of seven $(n=07)$ cell culture isolates of ORFV and thirty four $(n=34)$ suspected clinical materials in the form of skin lesions from different parts of the country were included to compare the LAMP and conventional PCR under this study. All the isolates and samples were tested by LAMP assay monitored by agarose gel analysis and simultaneously by conventional PCR optimized under this study to arrive at the rate of positive detection of ORFV. A total of thirty five $(n=35)$ ORFV positive samples identified by LAMP in agarose gel anlayis was used for comparative evaluation of three visual detection methods among themselves. To evaluate relative diagnostic specificity (Dsp) and sensitivity (Dsn) of LAMP assay, a total of twenty known positive samples which includes cell culture isolates and some positive clinical samples and also twenty known negative samples for ORFV were screened by LAMP while keeping semi-nested PCR (Inoshima et al., 2000) as golden standard test.

\section{RESULTS}

Optimization of LAMP ANd Conventional PCR The $B 2 L$ gene based ORFV LAMP method shown brighter and most distinct bands of different sizes (ladder-like pattern) in agarose gel analysis (Figure 2A) at optimized conditions. The reaction was performed at $65^{\circ} \mathrm{C}$ incubation for $45 \mathrm{~min}$ in a $25 \mu \mathrm{L}$ reaction volume containing $12.5 \mu \mathrm{L}$ of $2 \mathrm{x}$ reaction buffer [ $40 \mathrm{mM}$ Tris $\mathrm{HCl}, 20 \mathrm{mM} \mathrm{KCl}, 16$ $\mathrm{mM} \mathrm{MgSO} 4,20 \mathrm{mM}$ (NH4)2 SO4, 0.2\% Tween 20, 1.6 M Betaine, $1.6 \mathrm{mM}$ each dNTP], $1.0 \mu \mathrm{L}$ of primer mixture containing $1.6 \mu \mathrm{M}$ each of FIP, BIP, LF and LB primers and $0.2 \mu \mathrm{M}$ each of $\mathrm{F} 3$ and $\mathrm{B} 3$ primers, $8 \mathrm{U}$ of $B s t \mathrm{DNA}$ polymerase, $1 \mu \mathrm{L}$ of target DNA and $8.2 \mu \mathrm{L}$ of nuclease free water. The conventional PCR using $\mathrm{F} 3$ and $\mathrm{B} 3$ primers shown specific amplicon of $192 \mathrm{bp}$ in size at an annealing temperature of $55^{\circ} \mathrm{C}$ for $30 \mathrm{sec}$ as expected. The PCR product length was confirmed by commercial sequencing.

\section{Sensitivity and Specificity of LAMP Assay}

Agarose gel electrophoresis indicated that ORFV-LAMP primers did not react with GTPV and SPPV whereas it 
Table 2: Evaluation of PCR and B2L LAMP on clinical samples and comparative sensitivity of three visual detection methods

\begin{tabular}{|c|c|c|c|c|c|c|}
\hline \multirow[t]{2}{*}{ S No. } & \multirow{2}{*}{$\begin{array}{l}\text { Sample ID, Type of sample, Place of Collection, Date of } \\
\text { collection }\end{array}$} & \multirow[b]{2}{*}{ PCR } & \multicolumn{4}{|c|}{ LAMP detection methods } \\
\hline & & & AGA & Turbidity & SYBR green I & $\mathrm{HNB}$ \\
\hline 1 & 9/06, Goat scab, Jammu and Kashmir, India/06 & - & - & NA & NA & NA \\
\hline 2 & 1/06, Goat scab, Jammu and Kashmir,, India/06 & - & - & NA & NA & NA \\
\hline 3 & SP17,Goat scab, Jammu \& Kashmir, India/07 & - & + & + & + & + \\
\hline 4 & 82/04,Goat scab, Sahjahanpur, Uttar Pradesh, India/04 & + & + & + & + & + \\
\hline 5 & 12/06, Goat scab, Orissa, India/06 & + & + & + & + & + \\
\hline 6 & 13/06, Goat scab, Orissa, India/06 & + & + & + & + & + \\
\hline 7 & SP51, Goat scab, Palampur, Himachal Pradesh, India/08 & - & + & + & + & + \\
\hline 8 & 20/06, Goat scab, Palampur, Himachal Pradesh, India/06 & + & + & + & + & + \\
\hline 9 & SP26, Goat scab, Gujarat, India/06 & + & + & + & + & + \\
\hline 10 & 89/05, Mouth lesion, Goat, Bangalore, Karnataka, India/05 & + & + & + & + & + \\
\hline 11 & VSP68/1,Sheep scab, Tamil Nadu, India, 22.02.08 & + & + & + & + & + \\
\hline 12 & 143/05,Sheep scab, VBRI, Hyderabad, AP, India, 23.05.05 & + & + & + & + & + \\
\hline 13 & VSP5M/14,Goat scab, Hyderabad, AP ,India/08 & - & - & NA & NA & NA \\
\hline 14 & VSP5M/15,Goat scab, Hyderabad, AP, India/08 & - & - & NA & NA & NA \\
\hline 15 & 40/06 Goat Scab, Bhopal, Madhya Pradesh/06 & + & + & + & + & + \\
\hline 16 & 41/06, Goat Scab, Bhopal, Madhya Pradesh, India/06 & + & + & - & + & + \\
\hline 17 & 42/06, Goat Scab, Bhopal, Madhya Pradesh, India/06 & + & + & + & + & + \\
\hline 18 & 50/06, Goat scab, Ludhiana, Punjab, India/06 & + & + & + & + & + \\
\hline 19 & 51/06, Goat scab, Ludhiana, Punjab, India/06 & + & + & - & + & + \\
\hline 20 & 52/06, Goat scab, Ludhiana, Punjab, India/06 & + & + & + & + & + \\
\hline 21 & 53/06, Goat scab, Ludhiana, Punjab, India/06 & + & + & + & + & + \\
\hline 22 & 54/06, Goat scab, Ludhiana, Punjab, India/06 & + & + & + & + & + \\
\hline 23 & 55/06, Goat scab, Ludhiana, Punjab, India/06 & + & + & + & + & + \\
\hline 24 & 25/06, Goat scab, VBRI, Hyderabad, AP, India/06 & - & - & NA & NA & NA \\
\hline 25 & AJM08/1, Goat scab, Ajmer, Rajasthan, India/08 & - & - & NA & NA & NA \\
\hline 26 & VSP8/09/3, Goat scab, Alwar, Rajasthan, India/08 & + & + & + & + & + \\
\hline 27 & VSP8/09/4, Goat scab, Alwar, Rajasthan, India/08 & + & + & + & + & + \\
\hline 28 & VSP8/09/5, Goat scab, Alwar, Rajasthan, India/08 & + & + & + & + & + \\
\hline 29 & 59/05, Goat Scab, Mukteswar, uttarakhand, India/5 & + & + & + & + & + \\
\hline 30 & 71/09, Sheep scab, Mukteswar, Uttarakhand, India/09 & + & + & + & + & + \\
\hline 31 & 61/09, Sheep scab, Mukteswar, Uttarakhand,India/09 & + & + & + & + & + \\
\hline 32 & 48/09, Sheep scab, Mukteswar, Uttarakhand, India/09 & + & + & + & + & + \\
\hline 33 & 83/09, Sheep scab, Mukteswar, Uttarakhand, India/09 & + & + & + & + & + \\
\hline 34 & 47/09, Sheep scab, Mukteswar, Uttarakhand, India/09 & + & + & + & + & + \\
\hline 35 & ORFV 79/04 & + & + & + & + & + \\
\hline 36 & ORFV Assam & + & + & + & + & + \\
\hline 37 & ORFV Bangalore & + & + & + & + & + \\
\hline 38 & ORFV Bhopal & + & + & + & + & + \\
\hline 39 & ORFV VBRI, Hyderabad & + & + & + & + & + \\
\hline 40 & ORFV Gujarat & + & + & + & + & + \\
\hline 41 & ORFV Mukteshwar/09 & + & + & + & + & + \\
\hline & No. of positive/total sample tested & $33 / 41$ & $35 / 41$ & $33 / 35$ & $35 / 35$ & $35 / 35$ \\
\hline
\end{tabular}


shown positive reaction only with ORFV isolates (Figure 2A). The assay did not react positive with other pox viruses (BPXV and CMLV) and also other viruses of sheep and goats (PPRV and BTV). The visual colorimetric detection of LAMP by using HNB \& SYBR Green I dyes have shown also similar kind of results to that of agarose gel analysis (Figure 2B and C) and it was also monitored by presence of turbidity in reaction mix. The analytical sensitivity of the assay indicated that the detection limit of ORFV-LAMP was 9 copies $/ \mu \mathrm{L}$ and is 10 times higher than that of conventional PCR ( 90 copies $/ \mu \mathrm{L})$. The sensitivity of LAMP reaction tested by adding SYBR green I dye indicated a similar range of sensitivity and was consistent to agarose gel electrophoresis (Figure 3).

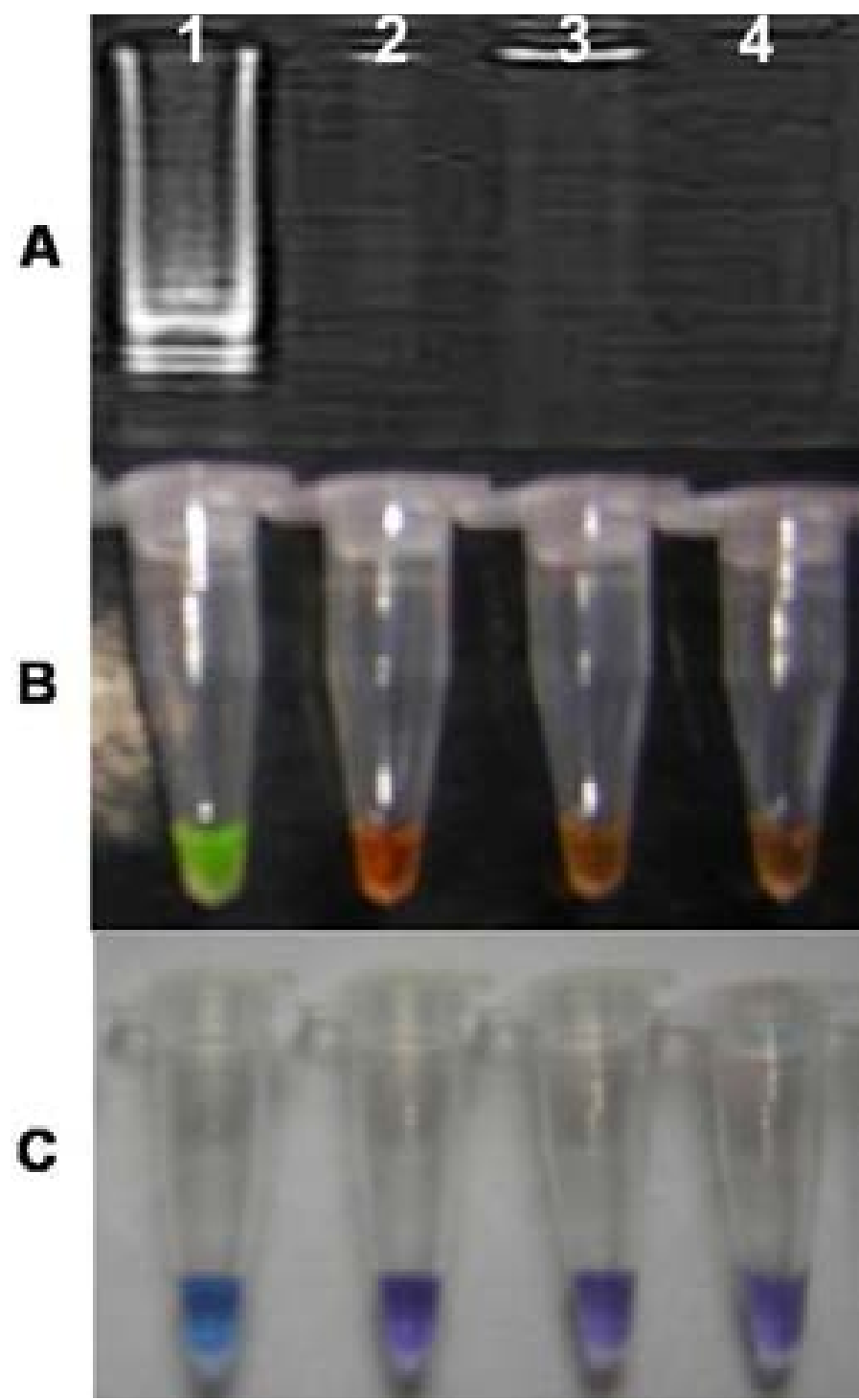

Figure 2: The analytical specificity of LAMP assay using purified viral DNA for detection ORFV

(A) 2.5\% agarose gel electrophoresis showing positive reaction for ORFV Muk (59/05)(Lane 1) and no such signal for SPPV and GTPV (Lane 2-3) and no template control (Lane 4); (B) SYBR green I dye showing colour change (Orange to apple green) in Tube 1 and negative controls (Tube 2-4) and (C) HNB dye showing colour change (violet to sky blue) in Tube 1 and negative controls (Tube 2-4)
Visual DeteCtion of LAMP REACTION

Three naked eye visualization methods for detection of positive LAMP reaction were optimized by using different concentration of MgSO4, SYBR green I $(10,000 \mathrm{X})$ and HNB $(3 \mathrm{mM})$ stock reagents. At a concentration of 0.8 $\mathrm{mM} \mathrm{MgSO} 4,1: 100$ of SYBR green I original stock and $120 \mu \mathrm{M}$ of HNB dye, positive LAMP reaction had shown an appreciable amount of turbidity, visible colour change from orange to apple green and violet to sky blue respectively and there was clear cut difference between positive and negative LAMP reaction for ORFV.

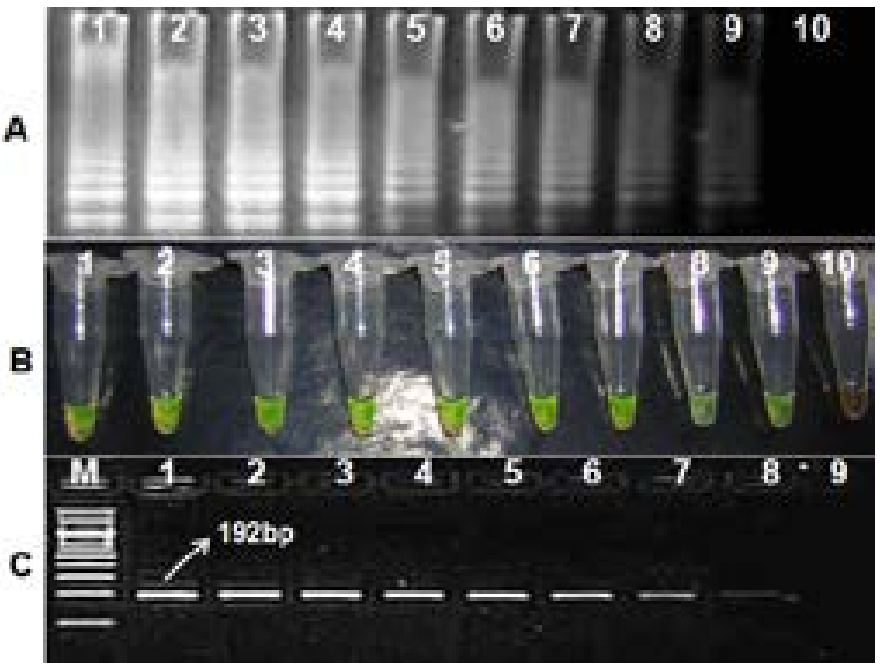

Figure 3: The analytical sensitivity of LAMP using 10 fold serially diluted plasmid DNA

(A) $2.5 \%$ agarose gel analysis showing LAMP reaction up to Lane 9 (9x10 copies); (B) Addition of SYBR green I showing color change up to Tube 9 ( $9 \times 10^{1}$ copies); (C) 2\% agarose gel electrophoresis showing specific amplification of target gene up to Lane $8\left(9 \times 10^{2}\right.$ copies $)$

\section{EVALUATION OF LAMP ASSAY}

All the ORFV isolates were detected positive by conventional PCR and LAMP assay based on all detection methods ( $\mathrm{EtBr}$ staining of agarose gel, turbidity, colour change due to addition of SYBR green and HNB). The result of successful detection of ORFV isolates by LAMP is shown in Figure 4A. The conventional PCR had shown 33 out of 41 clinical samples as positive whereas, LAMP assay indicated a total of 35 out of 41 as positive for ORFV. The results of selected clinical samples tested by LAMP in agarose gel analysis are shown (Figure 4B). The percentage positivity of the PCR and the LAMP assays were $80.5 \%$ and $85.3 \%$ respectively. Further, the detection rate of three visual detection methods were $94 \%, 100 \%$ and $100 \%$ respectively for turbidity, addition of SYBR green I and HNB dyes on these positive samples $(n=35)$ when compared to EtBr stained agarose gel analysis as standard. The relative DSp and DSn of the developed LAMP assay were found to be $100 \%(20 / 20 \times 100)$ and $100 \%(20 / 20 \times 100)$ respectively when compared to $B 2 L$ gene based nested PCR (Inoshima et al., 2000). 


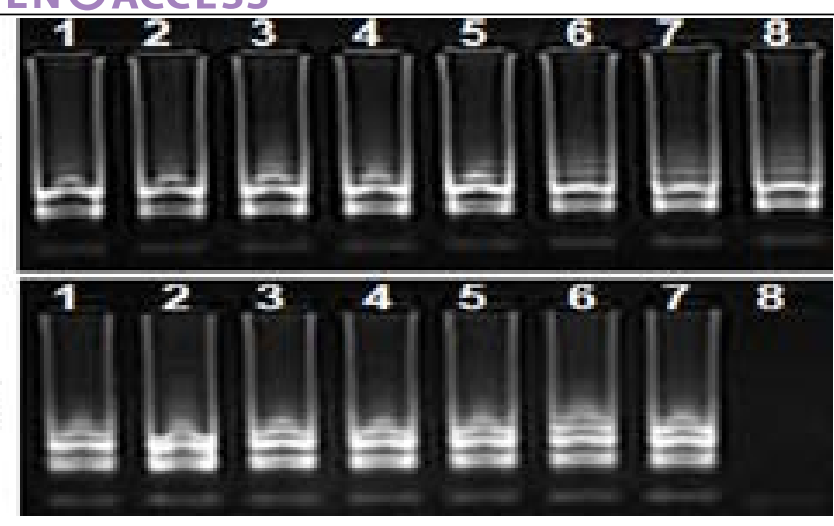

Figure 4: The ORFV B2L LAMP showing positive amplification of ORFV isolates (A) and selected clinical samples (B) using optimized conditions in $2.5 \%$ agarose gel electrophoresis

\section{DISCUSSION}

A rapid, highly sensitive and specific detection strategy for ORFV with ease of visualization of results will be a point of care diagnosis to overcome drawbacks associated with conventional and molecular diagnostic approaches (Parida et al., 2008). The developed ORFV LAMP targeting B2L gene under this study had shown optimum amplification within 45 min with high specificity and sensitivity. The developed LAMP was found highly specific for ORFV as there was no reactivity with capripox and also orthopox viruses. The improved specificity and consistent results of LAMP rely on binding of six primers to eight different regions of target gene as reported earlier (Nagamine et al., 2002). The LAMP assay is a simple diagnostic tool in which the reaction is carried out in a single tube by mixing the buffer, primers and strand displacement $D N A$ polymerase and LAMP has the advantages for detection sensitivity and reaction simplicity over PCR/real-time PCR assays (Venkatesan et al., 2012). The sensitivity of ORFV LAMP is found to be better than conventional PCR as reflected in analytical and diagnostic sensitivity evaluation of LAMP with PCR and it can be used for clinical diagnosis and epidemiological survey of orf in a large scale manner in field conditions. High specificity of LAMP assay is due to binding of 4-6 primers to complimentary regions of target genome (Notomi et al., 2000). Earlier, B2L gene has been targeted for development of LAMP assay (Tsai et al., 2009). However, it has been reported that only 70\% detection rate Vs nested PCR and only SYBR green I but not HNB dye has been used for monitoring/visualization of LAMP reaction. But, B2L LAMP under this study have shown better rate of detection on clinical samples compared to PCR and pre-addition of HNB dye did not inhibit the amplification efficiency of LAMP as reported earlier (Goto et al., 2009) and could be economically affordable in field conditions compared to SYBR green I, though both are equally sensitive in monitoring of LAMP reaction. LAMP primers targeted in this study have been selected from highly conserved region of $B 2 L$ gene after aligning twenty five gene sequences of different parapox virus isolates retrieved from GenBank database. This $B 2 L$ gene based LAMP assay shown comparatively less detection rate on clinical samples but shown almost equal analytical sensitivity compared DNA Polymerase (DPO) gene LAMP assay reported earlier (Venkatesan et al., 2015). It may be wise to rely on using two different target genes based diagnostic assays to avoid any false positive and false negative results in clinical diagnosis and surveillance of any infectious disease. B2L LAMP assay could be a handful and corroborative test for rapid screening of orf in sheep and goats along with DPO LAMP assay during the different phases of eradication process for the control of the disease in India. Accumulation of magnesium pyrophosphate in LAMP reaction tube as the time progress will be of simple and safe method to check the LAMP ( $\mathrm{Na}^{-}$ gamine et al., 2001). However, the other visual detection methods using SYBR green I and HNB were also found more sensitive than turbidity method for specific detection of ORFV genome from cell culture isolates and suspected clinical samples from sheep and goats. The difficulty associated with detection methods of LAMP in field laboratory settings will prevent its applicability. But, low cost, ease of visualization without need of any instruments, and plasticity of the metal ion indicators namely HNB (Goto et al., 2009) and malachite green (Nzelu et al., 2014; Nathan et al., 2015) could be handful to achieve a point of care diagnostic field applicability of this isothermal amplification assay. Further, visual observation of LAMP reaction by colorimetric detection using SYBR green I and HNB dyes will reduce the time taken for diagnosis in field conditions and avoid handling high cost equipment and unsafe reagents associated with post LAMP amplification analysis (Parida et al., 2008).

In conclusion, the developed LAMP assay targeting $B 2 L$ gene is found to be cost effective and time saving approach compared to high cost involving PCR and real time PCR methods. Further, LAMP reactions were analysed by three different visual detection methods (presence of turbidity, colour change by addition of SYBR green I and HNB dyes) comparing to agarose gel analysis and these methods were found to be simple, effective and safe when compared to the later. It has potential for rapid clinical diagnosis and epidemiological survey of virus strains of heterogeneity along with other molecular tools in resource limited field diagnostic laboratories of developing countries like India.

\section{ACKNOWLEDGEMENT}

The authors thank the Director, Indian Veterinary Research Institute (IVRI), for providing all the facilities to carry out this research work. The authors also thank $\mathrm{Di}$ rectors and staff of regional diagnostic laboratories of State Animal Husbandry Departments for sending clinical sam- 
ples to Pox Laboratory, IVRI, Mukteswar for diagnostic investigation. This study was supported by grants from the Department of Biotechnology, Government of India, New Delhi, India (BT/385/NE/TBP/2012)

\section{CONFLICT OF INTEREST}

There is no conflict of interest

\section{AUTHOR'S CONTRIBUTION}

GV designed and worked out the study. VB and VB helped in statistical anlaysis of data. DPB, YA and AK, SA and AM provided the technical support. DM and ABP helped in MS drafting and English editing.

\section{REFERENCES}

-Abrahao JS, Campos RK, Trindade GS, Guedes MI, Lobato ZI, Mazur C, Ferreira PC, Bonjardim CA, Kroon EG (2009). Detection and phylogenetic analysis of Orf virus from sheep in Brazil: A case report. Virol. J. 6:47. http:// dx.doi.org/10.1186/1743-422X-6-47

-Bora DP, Venkatesan G, Bhanuprakash V, Balamurugan V, Prabhu M, Sivasankar MS, Yogisharadhya Y (2011).TaqMan real-time PCR assay based on DNA polymerase gene for rapid detection of Orf infection. J.Virol. Methods. 178: 249-252. http://dx.doi.org/10.1016/j.jviromet.2011.09.005

- Bora DP, Barman NN, Das SK, Bhanuprakash V, Yogisharadhya R, Venkatesan G, Kumar A, Rajbongshi G, Khatoon E, Chakraborty A, Bujarbaruah KM (2012). Identification and phylogenetic analysis of orf viruses isolated from outbreaks in goats of Assam, a northeastern state of India. Virus Genes. 45(1): 98-104. http://dx.doi.org/10.1007/s11262012-0740-y

- Chan KW, Lin JW, Lee SH, Liao CJ, Tsai MC, Hsu WL, Wong ML, Shih HC (2007). Identification and phylogenetic analysis of orf virus from goats in Taiwan. Virus Genes. 35: 705-712. http://dx.doi.org/10.1007/s11262-007-0144-6

- Gallina L, Dal Pozzo F, McInnes CJ, Cardeti G, Guercio A, Battilani M, Ciulli S, Scagliarini A (2006). A real time PCR assay for the detection and quantification of orf virus. J. Virol. Methods. 134: 140-145. http://dx.doi.org/10.1016/j. jviromet.2005.12.014

- Goto M, Honda E, Ogura A, Nomoto, A, Hanaki K (2009). Colorimetric detection of loopmediated isothermal amplification reaction by using hydroxy naphthol blue. Biotechniques. 46:167-172. http://dx.doi. org/10.2144/000113072

- Guo J, Rasmussen J, Wünschmann A, de La Concha-Bermejillo A (2004). Genetic characterization of orf viruses isolated from various ruminant species of a zoo. Vet. Microbiol. 99(2): 81-92. http://dx.doi.org/10.1016/j.vetmic.2003.11.010

-Hosamani M, Bhanuprakash V, Scagliarini A, Singh RK (2006). Comparative sequence analysis of major envelope protein gene (B2L) of Indian orf viruses isolated from sheep and goats. Vet. Microbiol. 116: 317-324. http://dx.doi. org/10.1016/j.vetmic.2006.04.028

-Hosamani M, Scagliarini A, Bhanuprakash V, McInnes CJ, Singh RK (2009). Orf: An update on current research and future perspectives. Expert. Rev. Anti. Infect. Ther. 7: 879893. http://dx.doi.org/10.1586/eri.09.64

-Inoshima Y, Murakami K, Wu D, Sentsui H (2000). Detection and diagnosis of parapoxvirus by the polymerase chain reaction. J. Virol. Methods. 84(2): 201-208. http://dx.doi. org/10.1016/S0166-0934(99)00144-5

-Lederman ER, Green GM, DeGroot HE (2007). Progressive Orf virus infection in a patient with lymphoma: successful treatment using imiquimod. Clin. Infect. Dis. 44: e100-103. http://dx.doi.org/10.1086/517509

- Mondal B, Bera AK, Hosamani M, Tembhurne PA, Bandyopadhyay SK (2006). Detection of orf virus from an outbreak in goats and its genetic relation with other parapoxviruses. Vet. Res. Commun. 30: 531-539. http:// dx.doi.org/10.1007/s11259-006-3270-z

- Nagamine K, Hase T, Notomi T (2002). Accelerated reaction by loop-mediated isothermal amplification using loop primers. Mol. Cell. Probes. 16: 223-229. http://dx.doi.org/10.1006/ mcpr.2002.0415

- Nagamine K, Watanabe K, Ohtsuka K, Hase T, Notomi T (2001). Loop-mediated isothermal amplification reaction using a nondenatured template. Clin. Chem. 47: 1742-1743.

- Nathan A, Tanner, Yinhua Zhang, Thomas CE Jr (2015). Visual detection of isothermal nucleic acid amplification using $\mathrm{pH}-$ sensitive dyes. BioTechniques. 58: 59-68.

- Nitsche A, Büttner M, Wilhelm S, Pauli G, Meyer H (2006). Real-time PCR detection of parapoxvirus DNA. Clin. Chem. 52: 316-319. http://dx.doi.org/10.1373/ clinchem.2005.060335

- Notomi T, Okayaman H, Yonekawa T, Watanabe K, Amino N, Hase T (2000). Loop mediated isothermal amplification of DNA. Nucleic Acids Res. 28: E63. http://dx.doi. org/10.1093/nar/28.12.e63

-Nzelu CO, Gomez EA, Cáceres AG, Sakurai T, Martini-Robles L, Uezato H, Mimori T, Katakura K, Hashiguchi Y, Kato H (2014). Development of a loop-mediated isothermal amplification method for rapid mass-screening of sand flies for Leishmania infection. Acta Trop. 132:1-6. http://dx.doi. org/10.1016/j.actatropica.2013.12.016

-Parida M, Sannarangaiah S, Dash PK, Rao PV, Morita K (2008).Loop mediated isothermal amplification (LAMP): A new generation of innovative gene amplification technique; perspectives in clinical diagnosis of infectious diseases. Rev. Med.Virol. 18: 407-421.http://dx.doi.org/10.1002/rmv.593

-Tsai SM, Chan KW, Hsu WL, Chang TJ, Wong ML, Wang CY (2009). Development of a loop mediated isothermal amplification for rapid detection of orf virus. J. Virol. Methods. 157: 200-204.

-Venkatesan G, Bhanuprakash V, Balamurugan V, Singh RK, Pandey AB (2012). Development of loop-mediated isothermal amplification assay for specific and rapid detection of camelpox virus in clinical samples. J. Virol. Methods. 183(1): 34-39. http://dx.doi.org/10.1016/j. jviromet.2012.03.019

-Venkatesan G, Balamurugan V, Bhanuprakash V (2015). Development and comparative evaluation of loop mediated isothermal amplification (LAMP) assay for simple visual detection of orf virus in sheep and goats. Mol. Cell. Probes. 29(3):193-195. http://dx.doi.org/10.1016/j. mcp.2015.03.006

-Venkatesan G, Balamurugan V, Bora DP, Yogisharadhya R, Prabhu M, Bhanuprakash V (2011). Sequence and phylogenetic analyses of an Indian isolate of orf virus from 
-Venkatesan G, Bhanuprakash, Balamurugan V, Bora DP, Prabhu M, Yogisharadhya R, Pandey AB (2012). Rapid detection and quantification of Orf virus from infected scab materials of sheep and goats. Acta Virol. 56: 81-83. http:// dx.doi.org/10.4149/av_2012_01_81

-Yogisharadhya R, Bhanuprakash V, Venkatesan G, Balamurugan V, Pandey AB, Shivachandra SB (2012). Comparative sequence analysis of poxvirus A32 gene encoded ATPase protein and carboxyl terminal heterogeneity of Indian orf viruses. Vet. Microbiol. 156 (1-2): 72-80. http://dx.doi. org/10.1016/j.vetmic.2011.10.021

-Zhao K, Song D, He W, Lu H, Zhang B, Li C, Chen K, Gao F (2010). Identification and phylogenetic analysis of an Orf virus isolated from an outbreak in sheep in the Jilin province of China. Vet. Mcrobiol. 142: 408-415. http://dx.doi. org/10.1016/j.vetmic.2009.10.006 